\title{
Can Testicular Fibrosis Due to Testicular Torsion Be Prevented with Ketotifen As a Mast Cell Stabilizer?
}

\author{
Testis Torsiyonuna Bağlı Gelişen Testiste Fibrozis Mast Hücre \\ Stabilizatörü Olan Ketotifen ile Önlenebilir mi?
}

\author{
Müjdem Nur AZILI ${ }^{1}$, Hatice GERMEN ÜNVERDi², Sema HÜCÜMENOĞLU³ ${ }^{3}$ H.Tuğrul TiRYAKi
}

\author{
${ }^{1}$ Ankara Yildirim Beyazit University, Department of Pediatric Surgery, Ankara City Children's Hospital, Turkey \\ ${ }^{2}$ University of Kyrenia, Department of Pathology, Girne, Turkish Republic of Northern Cyprus \\ ${ }^{3}$ Ankara Education and Research Hospital, Department of Pathology, Ankara, Turkey \\ ${ }^{4}$ University of Health Sciences, Faculty of Medicine, Ankara City Children's Hospital, Department of Pediatric Urology, Ankara, Turkey
}

\begin{abstract}
Objective: In infertility clinics, biopsies taken from undescended atrophic testicles showed increased mast cells which are not found in normal testis. So, it was thought that mast cells could have a contributing effect on fibrosis leading to testicular atrophy. Our aim of the study is to investigate the efficacy of ketotifen, which is a mast cell stabilizer, on the prevention of testicular fibrosis in a testicular torsion-detorsion rat model.
\end{abstract}

Material and Methods: Thirty rats were divided into three equal groups, each consisting of ten animals. In group $\mathrm{A}$; the testicular tissues were only separated from the gubernaculum without torsion (Sham). In group B, detorsion was performed after four hours of testicular torsion in the right testes. In group C, after four hours of right testicular torsion and detorsion, the rats were taken ketotifen as a medical treatment $(1 \mathrm{mg} / \mathrm{kg} /$ day, orally started on the first day, continued for three weeks). The rats were sacrificed under anesthesia, three weeks after surgery to determine testicular fibrosis. Histopathologic evaluation was performed with Johnsen's score in both testes as a control evaluation.

Results: According to Johnsen score, median values were found 9.9 in group A; 3.7 in group B, and 8.4 in group C. Johnsen score was found significantly high in group $C$ (with ketotifen) when compared with the other groups $(p<0.05)$. When we made a pairwise comparison, we found a significant difference between the group's $A$ and $B(p=0.0001)$, the group's B and C; $(p=0.039)$, and the group's $A$ and $C(p=0.006)$.

Conclusion: We found that ketotifen had a preventing effect against testicular fibrosis as a mast cell stabilizer in the testis torsion-detorsion rat model.

Key Words: Ketotifen, Mast cell stabilizer, Testis torsion, Testicular fibrosis

\section{ÖZ}

Amaç: Infertilite kliniklerinde, inmemiş testis nedeni ile testis atrofisi gelişen olgu biopsilerinde testiste normalde olmayan mast hücreleri tespit edilmiştir. Buna bağlı olarak, testis atrofisine giden fibrozis sürecinde mast hücrelerinin katkısı olduğu düşünülmüştür. Çalışmamızda amaç, rat testis torsiyon- detorsiyon modelinde testiste gelişen fibrozisin önlemesi amacıyla bir mast hücre stabilizatörü olan ketotifenin etkinliğinin araştııımasıdır.

Gereç ve Yöntemler: Otuz rat, üç eșit gruba ayrıldı. Grup A' da testis yapıları gubernakulumdan ayrllip torsiyon yapmadan yerine kondu (sham). Grup B' de sağ testiküler torsiyon oluşturulup dört saat sonra detorsiyone edildi. Grup $C^{\prime}$ de dört saatlik torsiyonu takiben detorsiyon yapılan ratlara ketotifen $(1 \mathrm{mg} / \mathrm{kg} / \mathrm{gün}$, oral yolla, birinci günden itibaren üç haftaya kadar verildi). Ratlar, üç hafta sonra anestezi altında sakrifiye edilerek testiküler fibrozis gelişimi yönünden değerlendirildi. Histopatolojik değerlendirme Johnsen skoru kullanılarak yapıldı.

(1) AZILI MN GERMEN ÜNVERDI H HÜCÜMENOĞLU S TIRYAKI HT
Conflict of Interest / Çıkar Çatışması: On behalf of all authors, the corresponding author states that there is no conflict of interest.

0000-0002-5137-7209 :0000-0002-7065-5956 0000-0002-6898-4101 0000-0002-9544-1137
Ethics Committee Approval / Etik Kurul Onayı: This study was approved by the Ankara Training Hospital Ethical Committee for Experimental Research on Animals and supported by Ankara Child Health and Disease Hematology and Oncology Education Research Hospital Fund (5/3/15-21/349). Contribution of the Authors / Yazarların katkISI: AZILI MN: Designed and performed the experimental study and was responsible for the article in the drafting and writing phase, GERMEN ÜNVERDi H: Evaluated histopathological assessments, HÜCÜMENOĞLU S: Evaluated histopathological assessments, TiRYAKI TH: Controlled and revised the manuscript.

How to cite / Atıf yazım şekli : Azlı MN, Germen Ünverdi H, Hücümenoğlu S, Tiryaki HT. Can Testicular Fibrosis Due to Testicular Torsion Be Prevented with Ketotifen As A Mast Cell Stabilizer?. Turkish J Pediatr Dis 2021;15:234-238. 
Bulgular: Johnsen scorlarının median değerleri grup A, B, C’ de sırasıyla 9.9, 3.7 ve 8.4 bulundu. Grup C (ketotifen) diğer gruplar ile karşllaştıııldı̆̆ında, Johnsen skoru yüksekliği istatistiksel olarak anlamlı bulundu $(p<0.05)$ (Kruskall-Wallis). İkili karşılaștırma yapııldığında gruplar arasında anlamlı farklar olduğu saptandl: grup A-B; $\mathrm{p}=0.0001$, grup $\mathrm{B}-\mathrm{C} ; \mathrm{p}=0.039$, grup A-C; $\mathrm{p}=0.006$ ).

Sonuç: Bir testis torsiyon-detorsiyon rat modelinde, ketotifenin bir mast hücre stabilizatörü olarak testis fibrozisine karşı önleyici etkinliği olduğunu saptadık. Torsiyonlu erkek çocuklarda mast hücre ekspresyonunu germ hücre aktivitesi ile ilişkilendiren daha ileri çalısmalar yol gösterici olacaktır.

Anahtar Sözcükler: Ketotifen, Mast hücre stabilizatörü, Testis torsiyonu, Testiste fibrosis

\section{INTRODUCTION}

The excessive accumulation of extracellular matrix components in tissues is called fibrosis, but the initiating causes are still unknown. Fibrosis affecting organ systems may result in insufficiency or loss of functions. In recent years, the presence of increased mast cells (MCs) was shown in many fibrotic disorders like diabetes or hypertension-induced nephropathy, pulmonary fibrosis, liver diseases, and cardiac disorders (1). Also, the biopsies taken from patients with testicular atrophy due to undescended testis had determined increased mast cells that are not normally found in the testicle (2). Although the exact role of mast cells is not yet known, the growth factors and fibrotic agents released from MCs may be contributed to the process. The mechanisms that trigger excessive proliferation, activation of fibroblasts, and their differentiation into myofibroblasts may include the effects of pro-fibrotic growth factors. and proinflammatory stimuli (3).

Testicular torsion is the most important cause of acute scrotum in childhood. First, the testicle exposed to ischemic damage due to torsion. After detorsion, the oxygen radicals that develop due to reperfusion may cause secondary damage. Then, epithelialmesenchymal transition (EMT) and myofibroblast activation occur by proinflammatory cytokines as an inflammatory response. Unfortunately, testicular damage may not be limited to the affected side of torsion. Humoral and cellular immunemediated tissue injury may result in germ cell apoptosis in both testes where the mast cells play the main role (4).

Based on the hypothesis that if we can prevent the activation of mast cells, testicular atrophy and infertility resulting from fibrosis can be precluded, we aimed to investigate the effectiveness of ketotifen, as a mast cell stabilizer, in an experimental testicular torsion model.

\section{MATERIALS and METHODS}

This study was approved by the Ankara Training Hospital Ethical Committee for Experimental Research on Animals and supported by Ankara Child Health and Disease Hematology and Oncology Education Research Hospital Fund (5/3/15-21/349).

Thirty male Albino Wistar rats from 10-12 weeks weighing between 150-200 g were included. Animals were housed in pathogen-free conditions at room temperature $\left(22 \pm 2{ }^{\circ} \mathrm{C}\right)$ and subjected to a 12-hour light-dark cycle. The rats fed standard rat chow and tap water ad libitum. All experiments were performed according to the institutional guidelines for animal care and use.

Thirty rats were divided into three equal groups. Three groups, each consisting of ten rats were organized as a sham group, torsion-detorsion group, and torsion-detorsion with ketotifen treatment (Table I).

After ketamine anesthesia, the rats were laid supine. A right scrotal incision was used and the right testis was delivered out.

In group A, testicular tissues were separated from the gubernaculum without torsion (Sham). Then the testis was put into the scrotum and the incision was closed with $4 / 0$ silk.

In group B, a testicular detorsion procedure was performed after four hours of torsion in the right testes (Figure 1).

In group C, testis detorsion was applied after 4 hours of torsion, and then $1 \mathrm{mg} / \mathrm{kg} /$ day ketotifen was given orally after detorsion and continued for three weeks.

After three weeks, the rats went bilateral orchiectomies for gross and histologic examination of the testes to determine testicular fibrosis, and the sacrification was done under anesthesia.

The testes were fixed in 10\% neutral buffered formalin solution for 24 hours. All tissues were sampled, with slices taken from the widest axis. Paraffin blocks of the samples were prepared through a routine tissue follow-up procedure. Sections of 4-6 $\mu \mathrm{m}$ were cut from paraffin blocks and stained with hematoxylin and eosin. The stained sections were evaluated under a light microscope (Olympus BX 51; Olympus Corporation, Tokyo, Japan) by a pathologist who was not informed about the operations applied to the groups. At tissue samples, 100 seminiferous tubules were counted and scored with Johnsen score.

\section{Statistical Analysis}

Statistical analysis was performed using SPSS Statistics (Statistical Package for Social Science) for Windows, version 22.0 for Windows. A one-way ANOVA with the Kruskal-Wallis test was used for statistical analysis. The correlation between the study groups was determined with a pairwise comparison $p<0.05$ was considered statistically significant. 


\section{RESULTS}

The study was completed with 30 rats. Table $\|$ shows the results of the histopathological evaluation and the comparison of groups.

According to Johnsen's score, median values were found 9.9, 3.7, 8,4 in groups A, B, and C respectively. Johnsen's score was found significantly high in group $C$ (with ketotifen) when compared with the other groups $(p<0.05)$ (Kruskal-Wallis) (Table II).

When we made pairwise comparison, we found significant differences between group $A-B ; p=0.0001$, group $B-C$; $p=0.039$, group $A-C ; p=0.006)$.

The pathological views according to Johnsen's Scores are given in Figures 2, 3, 4.

\section{DISCUSSION}

Mast cells play an important role in fibrotic disorders. While the circulating renin-angiotensin system (RAS) regulates arterial pressure, paracrine RAS activation at the tissue level causes an increase in local Angiotensin II (Ang II) levels. "Chymase", a proteolytic enzyme also secreted from MCs, may contribute to the development of interstitial fibrosis. Today, angiotensinconverting enzyme inhibitors are widely used to eliminate the effects of Ang II, for the preventing effect of diabetic or hypertensive nephropathy. Numerous fibrinogenic and growth factors released from MCs may be the causes of fibrosis. Chronic inflammation results in organ dysfunction due to tissue destruction and sclerosis in the long term. But, the trigger mechanism for mast cell hyperactivity is still not known (5).

Welter and coll. observed peritubular myoid cells in human testes which were immunoreactive for Ang II receptors (AT1R). They detected high levels of IL-6 mRNA as an inflammatory response that led to an increase in Ang II values. Inflammatory effects resulting in increased Ang $\|$ may be the cause of male infertility (6). Also, Ang II can be produced from Ang I, by MCs-derived chymase. The testicular biopsies taken from infertile men had shown abundant MCs in the wall of the seminiferous tubules expressing chymase. In normal human testes, chymase-positive MCs are not often, and it is thought that these inflammatory processes may cause mast cell activation and result in impaired spermatogenesis. Especially the TGF- $\beta 1$-mediated mechanism is held responsible for autoimmune orchitis. This may be an answer to the question of why bilateral testes are affected in unilateral torsion $(7,8)$. Experimental studies have also shown serious contralateral testicle damage after unilateral torsion (9). Therefore, therapeutic intervention with the stabilization of mast
Table I: The groups, each consisting of ten rats were given in the table.

\begin{tabular}{c|c|c|c|c}
\hline Group & N & Torsion & Detorsion & Treatment \\
\hline A & 10 & No & No & - \\
B & 10 & Yes & After four hours & - \\
C & 10 & Yes & After four hours & Ketotifen \\
\hline
\end{tabular}

Table II: Johnsen's Scores according to the study groups, statistical analysis with Kruskal Wallis Test, with the pathological samples according to the groups.

\begin{tabular}{lcccc}
\hline & Group A & Group B & Group C & p \\
\hline $\begin{array}{l}\text { Johnsen's Score } \\
\text { (median) }\end{array}$ & 9.9 & 3.7 & 8.4 & $<0.05$ \\
$\begin{array}{l}\text { Pathological } \\
\text { samples }\end{array}$ & Figure 2 & Figure 3 & Figure 4 & \\
\hline
\end{tabular}

cells may be a new option in male infertility. We decided to use "ketotifen" as a mast cell stabilizer, to prevent inflammatory processes in an experimental testicular torsion model. Because both ischemic and reperfusion damages are the causes of testicular fibrosis. Although the reports have shown no difference between orchiectomy and detorsion groups for sperm parameters in early detorsion, recent studies point out the ischemia/reperfusion injury following reperfusion $(10,11)$. Timing for detorsion has also become an important issue since the experimental studies have shown that testicular necrosis may develop within 2 hours due to arterial occlusion (12).

Recently, male infertility has been understood more with immunohistopathological staining and even electron microscopic studies for evaluation of mast cells (6). The increased mast cells in the walls of seminiferous tubules have attracted attention in patients suffering impaired spermatogenesis (6). Also, testicular torsion-detorsion is one of the causes of low sperm parameters due to ischemia/reperfusion injury and Johnsen scores are also lower in experimental models (13). Unfortunately, hyperactivity of mast cells due to inflammatory stimuli similarly can result in germinal cell necrosis and infertility. In our torsion group, Johnsen's score was significantly lower than the other groups. According to our study groups, the detorsion group with ketotifen (group C) had a comparable Johnsen score with the sham group.

Ketotifen is a routine agent used to inhibit the release of mediators released from mast cells in the prevention of allergic asthma. In our experimental model is a good example to represent the chronic process of testicular fibrosis and autoimmune orchitis. The histopathological definition of increased mast cells in testes is well defined in autoimmune orchitis. Also, the beneficial use of ketotifen was reported in severe oligozoospermic male patients. In our study, ketotifen had a preventing effect against testicular fibrosis. The Johnsen scores were significantly high 


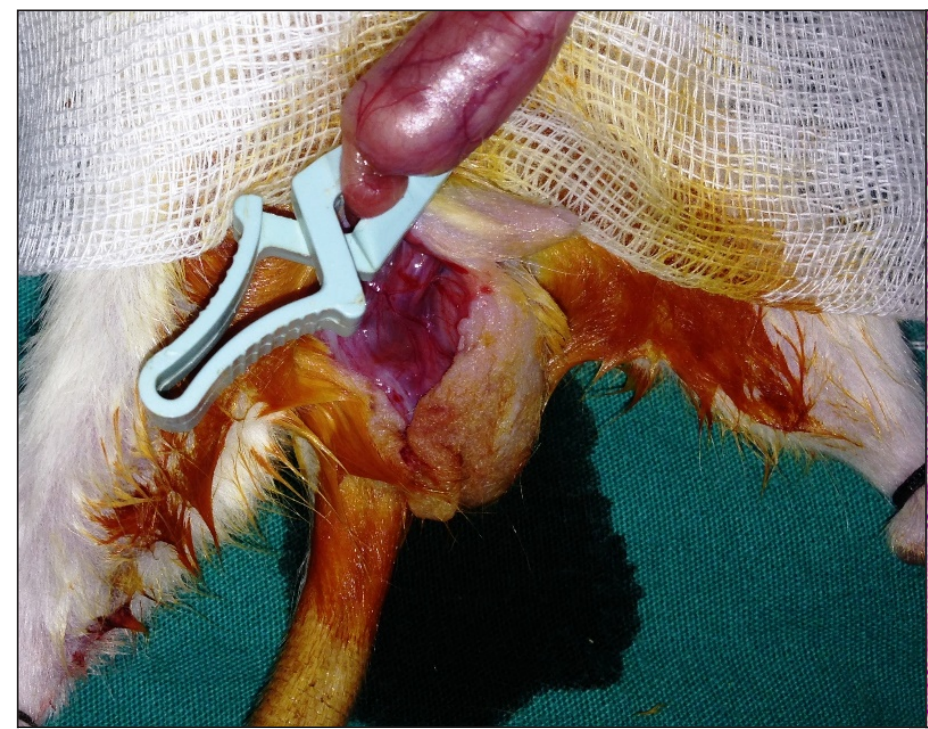

Figure 1: A view of testicular detorsion procedure in the right testes within four hours.

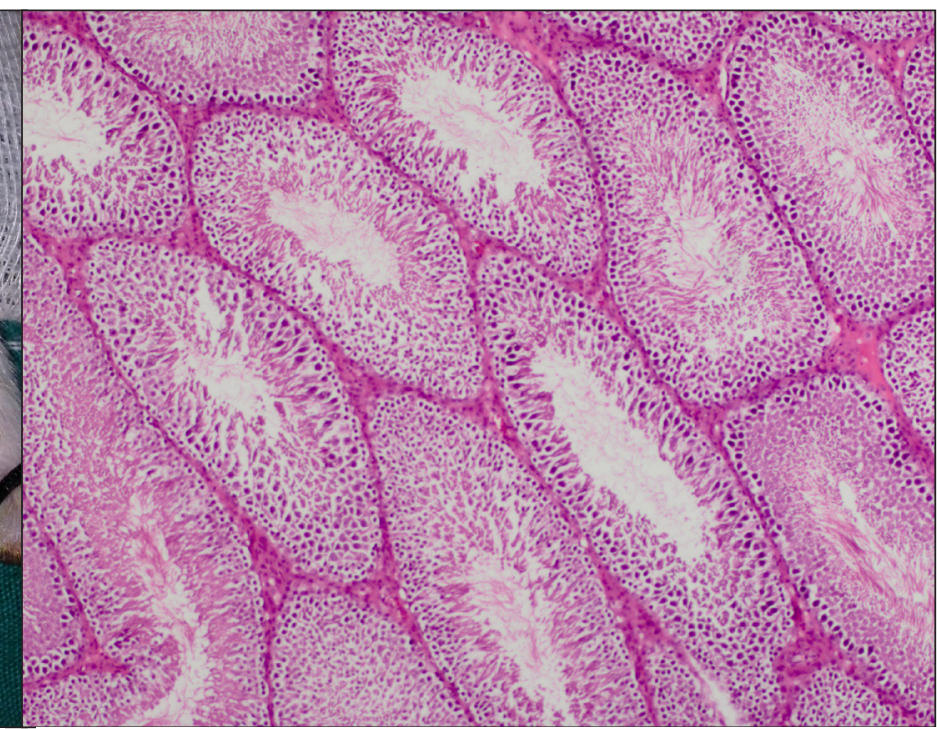

Figure 2: In group A, there are complete spermatogenesis and perfect tubules as a control group, the Johnsen score is 10 (H\&E x100)

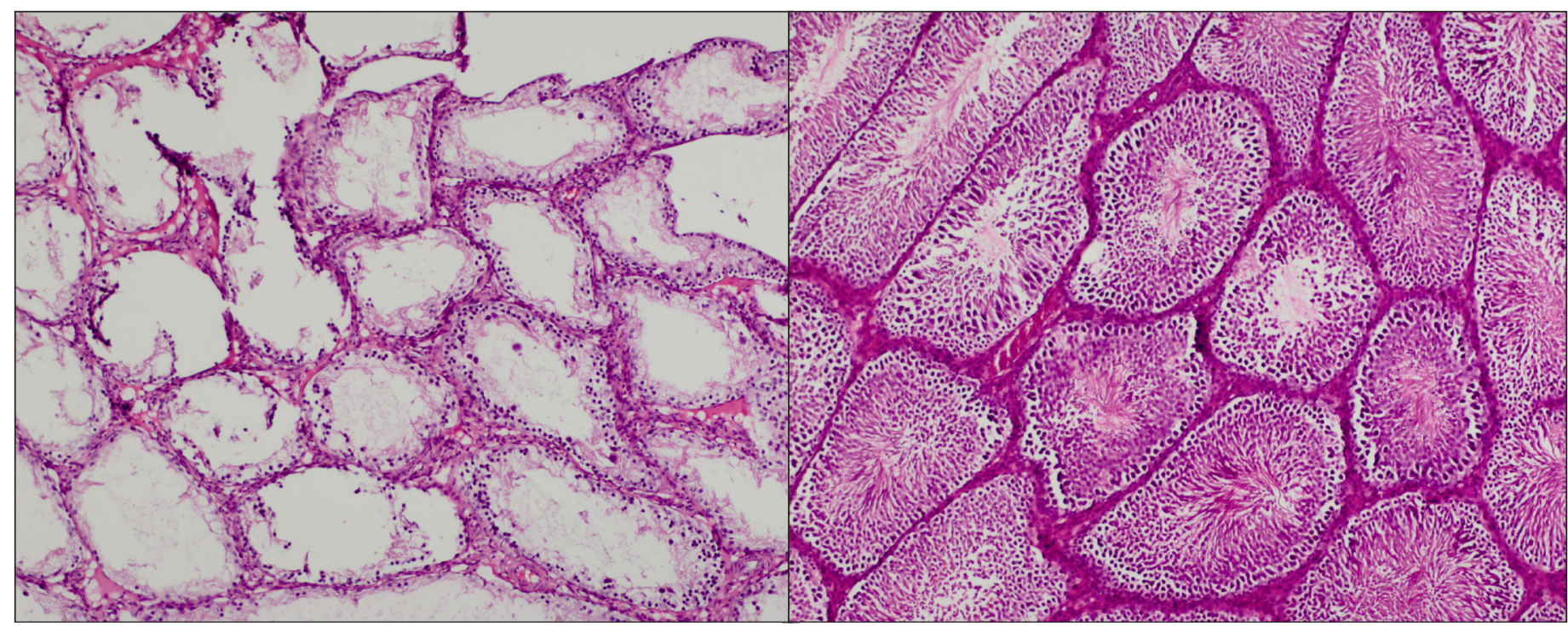

Figure 3: In one sample of group B, the Johnsen score is 2.4 (H\&E x100).

$\mathrm{x} 100$ ).

compared with the torsion group. According to the evaluation of the scoring system, we think that ketotifen was beneficial in terms of preserving spermatogenesis and preventing germ cell apoptosis, which is the most undesirable scenario. Further studies correlating mast cell expression with germ cell activity may contribute to understanding torsion-related long-term effects and prevention possibility.

Our study has some limitations. For the analysis of mast cell activity, immunological histopathological staining may help to understand the process. Proinflammatory cytokines can contribute to understanding the pathophysiology. Although the Johnsen score was used to determine whether spermatogenesis is affected, adding the fibrotic score to the histological evaluation may be beneficial.

\section{CONCLUSION}

We found that ketotifen had a preventing effect against testicular fibrosis as a mast cell stabilizer in the testis torsion-detorsion rat model. Further studies correlating mast cell expression with germ cell activity in testicular torsion are warranted.

\section{REFERENCES}

1. Wynn TA, Ramalingam TR. Mechanisms of fibrosis: therapeutic translation for fibrotic disease. Nat Med 2012;181028-40.

2. Mechlin CW, Levesque J, Feustel P, Kogan BA. Mast cell numbers negatively correlate with fibrosis in cryptorchid testes. J Pediatr Urol 2014;10:527-31 
3. Bradding P, Pejler $G$. The controversial role of mast cells in fibrosis. Immunol Rev 2018;282:198-231.

4. Acer-Demir T, Mammadov M, Öcbe P, Çoruhlu A, Coşkun D, Nazik $Y$, et al. The long term effects of intrascrotal low dose and high dose $\mathrm{N}$-acetylcysteine on testis damage in rat model of testicular torsion. J Pediatr Surg 2020;55:672-80.

5. Azııı MN, Karakuș E, Şenaylı A, Tiryaki Ht. Effects of Captopril and Ketotifen on Protecting Against Renal Scarring Due to Pyelonephritis Injury. Turkish J Pediatr Dis 2019; 6: 475-80.

6. Welter H, Huber A, Lauf S, et al. Angiotensin II regulates testicular peritubular cell function via AT1 receptor: a specific situation in male infertility. Mol Cell Endocrinol 2014;393:171-8.

7. Garbuzenko E, Nagler A, Pickholtz D, P Gillery, R Reich, F-X Maquart, et al. Human mast cells stimulate fibroblast proliferation, collagen synthesis and lattice contraction: a direct role for mast cells in skin fibrosis. Clin Exp Allergy 2002;32:237-46.

8. Moreno D, Sobarzo CM, Lustig L, Rodriguez Pena MG, Guazzone VA. Effect of ketotifen fumarate on experimental autoimmune orchitis and torsion of the spermatic cord. Asian $\mathrm{J}$ Androl 2020;22:112-7.

9. Akgur FM, Kilinc K, Tanyel FC, Buyukpamukcu N, Hicsonmez A. Ipsilateral and contralateral testicular biochemical acute changes after unilateral testicular torsion and detorsion. Urology 1994;44:413-8.

10. Anderson MJ, Dunn JK, Lipshultz LI, Coburn M. Semen quality and endocrine parameters after acute testicular torsion. J Urol 1992;147:1545-50.

11. Widgerow AD. Ischemia-reperfusion injury: influencing the microcirculatory and cellular environment. Ann Plast Surg2014;72:253-60.

12. Dubois $\mathrm{R}$, Dodat $\mathrm{H}$. Acute scrotum in the child. Arch Pediatr 1998;5:916-22.

13. Kutluhan MA, Urkmez A, Sahin A, Topaktas R, Gumrukcu $G$, Verit A. Predictive value of ischaemia-modified albumin in spermatogenesis in an experimental testicular torsion model. Andrologia 2020;52:e13471. 